\title{
JNVEST]GHACJÓN
}

\section{Changes in the phospholipid fraction of intramuscular fat from pork loin (fresh and marinated) with different irradiation and packaging during storage}

\author{
By I. García-Márquez ${ }^{\mathrm{b}}$, M. Narváez-Rivas ${ }^{\mathrm{a}}$, E. Gallardo ${ }^{\mathrm{a}}$, C.M. Cabeza ${ }^{\mathrm{b}}$ and M. León-Camacho ${ }^{\mathrm{a}, \text { * }}$
}

\author{
${ }^{a}$ Food Characterization and Quality Department. Instituto de la Grasa (C.S.I.C.). \\ Avda. Padre García Tejero, 4. 41012 Seville, Spain \\ ${ }^{\mathrm{b}}$ Department of Nutrition, Bromatology and Food Technology Faculty of Veterinary, University Complutense, \\ Avda. Puerta de Hierro, S/N, E-28040 Madrid, Spain \\ * Corresponding author: mleon@ cica.es
}

\section{RESUMEN}

Cambio en la fracción de fosfolípidos de la grasa intramuscular del lomo de cerdo (fresco y adobado) con diferentes irradiaciones y empaquetados durante el almacenamiento

Se ha realizado un estudio sobre el efecto de la radiación de electrones (E-beam) (1 y 2 kGy) en las clases de fosfolípidos del lomo de cerdo almacenado a 4 y $8^{\circ} \mathrm{C}$ bajo diferentes atmósferas ( aire, vacío y dióxido de carbono). Este tipo de estudio ha sido llevado a cabo por primera vez en este tipo de muestras. El tratamiento estadístico combinado de distintas variables muestran que se producen cambios menores en los fosfolípidos individuales sujetos a las diferentes condiciones seleccionadas (la cardiolipina y la esfingomielina se ven afectadas por el tipo de lomo, la cardiolipina por la temperatura de almacenamiento y la fosfatidiletanolamina por las atmósferas modificadas). El resultado más relevante fue que no hubo efecto de la dosis de radiación en las diferentes clases de fosfolípidos, por lo que la radiación E-beam se convierte en una herramienta útil para prolongar la vida útil de la carne fresca sin producir cambios en la fracción de fosfolípidos de ésta.

PALABRAS CLAVE: Adobado - Clases de fosfolípidos - E-beam - Empaquetado - Fresco - HPLC - Lomo de cerdo-Radiación.

\section{SUMMARY}

Changes in the phospholipid fraction of intramuscular fat from pork loin (fresh and marinated) with different irradiation and packaging during storage

A study on the effect of E-beam (1 and 2 kGy) on the phospholipid classes of fresh and marinated pork loin stored at $4^{\circ} \mathrm{C}$ and $8^{\circ} \mathrm{C}$ under different atmospheres (air, vacuum and carbon dioxide enriched atmospheres) has been conducted. This is the first time that a study of this kind has been carried out on these types of samples. The combined statistical treatment of the distinct variables shows that minor changes (cardiolpin and sphingomyelin between both types of loin, cardiolipin vs storage temperatures and phosphatidylethanolamine vs the modified atmospheres) are produced in the individual phospholipids subjected to the different selected conditions. The more relevant result was that no effect of the irradiation doses on the phospholipids classes was found, so the E-beam can be considered a useful tool to extend the shelf-life of fresh meat without changes in the phospholipid fraction.

KEY-WORDS: E-beam - Fresh - HPLC - Irradiation Marinated - Packaging - Phospholipid classes - Pork loin.

\section{INTRODUCTION}

According to FAO statistics, pork is the most widely produced meat in the world. Europe ranks second in the production of pigs and pig meat, and its production represents $22.6 \%$ of the total. The European Union reported a consumption of about 20 million metric tons in the year 2004 (Ministerio de Comercio Exterior, 2007). In Spain, the porcine sector is the principal group; with a consumption of pigs' meat of about $62 \mathrm{~kg} /$ per capita / year, well above other meats, both red and white (MARM, 2000). This acceptance is due to its sensory characteristics, which are conferred by their lipid composition, mainly the products from the Iberian bred (an indigenous, black footed, fine skeleton and long legged breed with adipogenic ability). Most of the aroma compounds of raw and cooked meat arise from lipid oxidation during storage and processing (Gandemer, 2002). Lipid content has often been reported to influence the sensory traits of texture, tenderness, flavor, and juiciness (CandekPotokar et al., 1998; Lonergan et al., 2001; HuffLonergan et al., 2002; Gandemer, 2002).

Food irradiation is a physical process for food preservation based on the application of radiation associated with enough energy to separate electrons from molecules in food, turning them into ions. It is a technology which has been well-known since the 1980's, but hardly used because it cannot compete with heat treatments. However, it has been observed that some of the forms of radiation, namely accelerated electrons (E-beam), present a 
good opportunity for extending the shelf-life of meat pieces for distribution to large distances, minimizing, at the same time, cross contamination. Likewise, the E-beam treatment has been ascertained to be very useful for sanitizing ready-to-eat foods (RTE), including pork products (Cabeza et al., 2007; Hoz et al., 2008; Cabeza et al., 2009) since it is not possible to apply a heat treatment to already packed RTE foods. The efficacy of ionizing radiation to prevent or delay the food spoilage and eliminate vegetative pathogen organisms has been well established. It has been reported to increase shelf life (Mitchell, 1994) with a 0.25 to $1 \mathrm{kGy}$ dose under aerobic conditions, although adverse effects may be produced (vitamin destruction, accelerated lipolytic rancidity, formation of free radicals). To support this view, we may cite the wide optimization program that the Thayer's group in the USA has been developing since 1995, aimed at achieving this goal for beef and pork (Thayer et al., 1993). Recently, it has been demonstrated that E-beam is a very useful procedure to both extend the shelf-life and to reach the objective of Food Safety (FSO) in a variety of RTE products. However, some researchers have suggested (Ahn et al., 2000; Du et al., 2002; Patterson and Stevenson, 1995) that the use of this technology in meat products is limited because of the resulting changes in the aroma, color and flavor, which can significantly affect consumer acceptance. Radiation could accelerate oxidation reactions and it may produce undesirable compounds (Chen et al., 1999; Groninger et al., 1956; Lambert et al., 1992; Lefebvre et al., 1994; Thayer et al., 1993).

Nowadays, some of the most prevalent food preservation technologies are modified atmosphere packaging (MAP) and vacuum packaging. Modified atmosphere packaging consists of changing the gas atmosphere in the product's environment. It extends the shelf-life of raw meat and fish by suppressing or slowing down the growth of gram-negative psychrotrophic bacteria, mainly Pseudomonas spp. and other Gram-negative organisms, which a cause rapid spoilage of food aerobically stored as a result of the accumulation of end products from metabolism (Church and Parsons, 1995; Livingston et al., 2004). Vacuum packaging decreased the micro-biological diversity in chilled pork during storage, with the lactic acid bacteria (LAB) being the dominant organism, which grows slower than the aerobic Gram-negative, resulting in an extension of the shelflife (Dainty and Mackey, 1992; Olsson et al., 2003). Some of the compounds that may be affected by the type of packaging or irradiation could be the phospholipids (PL), which are integral compounds of cell membranes in animal and plant tissues. They are involved in the functioning of cell membranes and in their ability to interact with metabolites, ions, hormones, antibodies and other cells (Cambero et al., 1991; Weihrauch and Son, 1983). One of the most important factors in lipid composition is the amount of intramuscular phospholipids in the meat for the flavor and nutritive quality of meat products (Ali et al., 2007; Choi, 2009; García et al., 1994; Sasaki et al., 2008).
Several authors have investigated the degree of lipid oxidation through the determination of volatile compounds. The Maillard reaction system containing phospholipids produced many lipid-derived volatile compounds which give fatty aromas to cooked meat and the characteristic coming from the interaction of the Maillard reaction and lipids (Chiu et al., 1990; Mottram and Whitfield, 1995). Volatile compounds produced during the $\mathrm{FeCl}_{3}$-sodium ascorbatecatalyzed oxidation of phospholipids and extracted from pork muscle by high-performance liquid chromatography were checked by Meynier et al. (1998). The flavor contribution of triglycerides and phospholipids to pork was also studied, showing that the flavor differences between two different breeds and two different defatting treatments (removing intramuscular triglycerides or total lipids) (Huang et al., 2010). Finally, an analytical method for the isolation, resolution and quantification of phospholipid classes applicable to different types of matrices, has been developed in another study. This method has been applied to subcutaneous fat from the Iberian pig (Narváez-Rivas et al., 2011), analyzing the different phospholipid classes by HPLC.

The aim of this work is to study for the first time the modification produced in the different phospholipid classes from fat extracted from fresh and marinated pork loin slices subjected to E-beam irradiation once packed under different atmospheres. As control, non-irradiated samples were used.

\section{MATERIALS AND METHODS}

\subsection{Reagents and standards}

Hexane, a fraction from petroleum, Multisolvent TM HPLC ACS grade supplied by Scharlau (Barcelona, Spain) was distilled through a fractionation column. Chloroform, methanol, diethyl ether, ammonia solution and 2-propanol for analysis grade were provided by Merck (Darmstadt, Germany). A phospholipid standard solution (ref: P3817-1VL) containing phosphatidylethanolamine (PE), phosphatidylcholine, (PC) phosphatidylinositol, (PI), phosphatidylserine (PS), and lysophosphatidylcholine (LPC) was purchased from Supelco (Bellefonte, PA, USA). Triethylamine, cardiolipin (CL) and sphingomyelin (SPH) were purchased from Sigma Chemical Co. (St. Louis, MO, USA) and were used as standard. Chloroform and methanol, both LiChrosolv grade, were supplied by Merck (Darmstadt, Germany) and were used as HPLC solvents. All other materials were analytical grade.

\subsection{Samples and Sample treatment}

A total of fifty-four samples of fresh and marinated (prepared by injection of a brine composed of salt, ascorbic acid, nitrite, garlic, paprika and others) loin from castrated male white pigs were used. Table 1 shows the E-beam treatment applied and the identification code 
Table 1

Intramuscular fat from pork loin samples

\begin{tabular}{|c|c|c|c|c|c|}
\hline Code & Type & $\begin{array}{c}\text { Temperature } \\
\left({ }^{\circ} \mathrm{C}\right)\end{array}$ & Atmosphere & $\begin{array}{c}\text { Radiation } \\
\text { (kGy) }\end{array}$ & $\begin{array}{c}\text { Time } \\
\text { (days) }\end{array}$ \\
\hline $1 F$ & Fresh & 4 & Air & 0 & 0 \\
\hline $2 \mathrm{~F}$ & Fresh & 4 & Air & 1 & 0 \\
\hline $3 F$ & Fresh & 4 & Air & 2 & 0 \\
\hline $4 \mathrm{~F}$ & Fresh & 4 & Vacuum & 0 & 0 \\
\hline $5 \mathrm{~F}$ & Fresh & 4 & Vacuum & 1 & 0 \\
\hline $6 \mathrm{~F}$ & Fresh & 4 & Vacuum & 2 & 0 \\
\hline $7 F$ & Fresh & 4 & MAP & 0 & 0 \\
\hline $8 \mathrm{~F}$ & Fresh & 4 & MAP & 1 & 0 \\
\hline $9 \mathrm{~F}$ & Fresh & 4 & MAP & 2 & 0 \\
\hline $10 \mathrm{~F}$ & Fresh & 4 & Air & 0 & 10 \\
\hline $11 \mathrm{~F}$ & Fresh & 4 & Air & 1 & 10 \\
\hline $12 \mathrm{~F}$ & Fresh & 4 & Air & 2 & 10 \\
\hline $13 F$ & Fresh & 4 & Vacuum & 0 & 10 \\
\hline $14 \mathrm{~F}$ & Fresh & 4 & Vacuum & 1 & 10 \\
\hline $15 F$ & Fresh & 4 & Vacuum & 2 & 10 \\
\hline $16 \mathrm{~F}$ & Fresh & 4 & MAP & 0 & 10 \\
\hline $17 \mathrm{~F}$ & Fresh & 4 & MAP & 1 & 10 \\
\hline $18 \mathrm{~F}$ & Fresh & 4 & MAP & 2 & 10 \\
\hline $19 \mathrm{~F}$ & Fresh & 8 & Air & 0 & 10 \\
\hline $20 \mathrm{~F}$ & Fresh & 8 & Air & 1 & 10 \\
\hline $21 \mathrm{~F}$ & Fresh & 8 & Air & 2 & 10 \\
\hline $22 \mathrm{~F}$ & Fresh & 8 & Vacuum & 0 & 10 \\
\hline $23 F$ & Fresh & 8 & Vacuum & 1 & 10 \\
\hline $24 \mathrm{~F}$ & Fresh & 8 & Vacuum & 2 & 10 \\
\hline $25 \mathrm{~F}$ & Fresh & 8 & MAP & 0 & 10 \\
\hline $26 \mathrm{~F}$ & Fresh & 8 & MAP & 1 & 10 \\
\hline $27 \mathrm{~F}$ & Fresh & 8 & MAP & 2 & 10 \\
\hline $1 \mathrm{M}$ & Marinated & 4 & Air & 0 & 0 \\
\hline $2 \mathrm{M}$ & Marinated & 4 & Air & 1 & 0 \\
\hline $3 \mathrm{M}$ & Marinated & 4 & Air & 2 & 0 \\
\hline $4 \mathrm{M}$ & Marinated & 4 & Vacuum & 0 & 0 \\
\hline $5 \mathrm{M}$ & Marinated & 4 & Vacuum & 1 & 0 \\
\hline $6 \mathrm{M}$ & Marinated & 4 & Vacuum & 2 & 0 \\
\hline $7 \mathrm{M}$ & Marinated & 4 & MAP & 0 & 0 \\
\hline $8 M$ & Marinated & 4 & MAP & 1 & 0 \\
\hline $9 \mathrm{M}$ & Marinated & 4 & MAP & 2 & 0 \\
\hline $10 \mathrm{M}$ & Marinated & 4 & Air & 0 & 10 \\
\hline $11 \mathrm{M}$ & Marinated & 4 & Air & 1 & 10 \\
\hline $12 \mathrm{M}$ & Marinated & 4 & Air & 2 & 10 \\
\hline $13 \mathrm{M}$ & Marinated & 4 & Vacuum & 0 & 10 \\
\hline $14 \mathrm{M}$ & Marinated & 4 & Vacuum & 1 & 10 \\
\hline $15 \mathrm{M}$ & Marinated & 4 & Vacuum & 2 & 10 \\
\hline $16 \mathrm{M}$ & Marinated & 4 & MAP & 0 & 10 \\
\hline $17 \mathrm{M}$ & Marinated & 4 & MAP & 1 & 10 \\
\hline $18 \mathrm{M}$ & Marinated & 4 & MAP & 2 & 10 \\
\hline $19 M$ & Marinated & 8 & Air & 0 & 10 \\
\hline $20 \mathrm{M}$ & Marinated & 8 & Air & 1 & 10 \\
\hline $21 \mathrm{M}$ & Marinated & 8 & Air & 2 & 10 \\
\hline $22 \mathrm{M}$ & Marinated & 8 & Vacuum & 0 & 10 \\
\hline $23 \mathrm{M}$ & Marinated & 8 & Vacuum & 1 & 10 \\
\hline $24 \mathrm{M}$ & Marinated & 8 & Vacuum & 2 & 10 \\
\hline $25 \mathrm{M}$ & Marinated & 8 & MAP & 0 & 10 \\
\hline $26 \mathrm{M}$ & Marinated & 8 & MAP & 1 & 10 \\
\hline $27 \mathrm{M}$ & Marinated & 8 & MAP & 2 & 10 \\
\hline
\end{tabular}


assigned to each one. The lipids were obtained from 10 grams of each sample by extraction with chloroform-methanol $(2: 1 \mathrm{v} / \mathrm{v})$ according to the procedure described by Folch et al. (1957). The samples were cut up into small pieces and homogenized before extraction with $3 \times 50 \mathrm{~mL}$ of solvent, then $100 \mathrm{~mL}$ of distilled water were added. The chloroform solution was filtered over anhydrous sodium sulphate, and the samples were extracted with $3 \times 50 \mathrm{~mL}$ of diethyl ether. The extracts were combined with the chloroform solution and then evaporated to dryness in a rotary evaporator at $30^{\circ} \mathrm{C}$ under reduced pressure. The phospholipid fraction was separated from the extracted lipids by means of Solid Phase Extraction (SPE) according to the method of Narváez-Rivas et al. (2011). An aliquot $(200 \mathrm{mg})$ of the lipid extract was dissolved in $1.0 \mathrm{~mL}$ of hexane and then transferred into a silica gel bonded column, Supelclean LC-Si, $6 \mathrm{~mL}$ volume; $1 \mathrm{~g}$ sorbent (Supelco Bellefonte, PA, USA) which was previously conditioned with $10 \mathrm{~mL}$ n-hexane. The column was washed with $10 \mathrm{~mL} n$-hexane:diethyl ether $(4: 1 \mathrm{v} / \mathrm{v})$, to remove free fatty acids, and then hydrocarbons, cholesterol esters and triacylglycerols were eluted with $18 \mathrm{~mL}$ of chloroform:2-propanol $(2: 1 \mathrm{v} / \mathrm{v})$. The phospholipids were recovered with $10 \mathrm{~mL}$ of methanol and finally washed with a $10 \mathrm{~mL}$ solution of methanol:chloroform:water (5:3:2 v/v/v). The recovered fraction was evaporated to dryness in a rotary evaporator at $30^{\circ} \mathrm{C}$ under reduced pressure and the residue was re-dissolved in $0.2 \mathrm{~mL}$ of chloroform for the HPLC analysis.

\subsection{Analysis of phospholipids}

The different phospholipid classes were analyzed by HPLC according to the method previously described (Narváez-Rivas et al., 2011). The HPLC system consisted of an Agilent (Palo Alto, CA, USA) 1100 liquid chromatograph with a quaternary pump, an autosampler with variable injection volume $(0$ to $100 \mu \mathrm{L})$, a Peltier furnace and an evaporative light scattering detector Alltech ELSD 2000 (Deerfield, IL, USA). A Chemical Station HP was used for controlling and monitoring the system. Separation was performed in a $100 \times 4.6 \mathrm{~mm}$ macropores size $2.1 \mu \mathrm{m}$ and mesopores size $13 \mathrm{~nm}$ Chromolith Performance Si column Merck (Darmstadt, Germany). The temperature of the column was held at $25^{\circ} \mathrm{C}$. A gradient elution was carried out using different ratios of solutions $A$ (chloroform: methanol:ammonia solution, 80:19.5:0.5, v/v/v) and B (chloroform:methanol:triethylamine:water, 69.53:25.58:0.49:4.40, v/v/v/v). The best separation was obtained using the following gradient: from 0 to $5 \mathrm{~min}$, B was increased from $0 \%$ to $40 \%$; from 5 to 7 min; B was kept constant at $40 \%$; from 7 to 13 min and was increased from $40 \%$ to $100 \%$; from 13 to 20 min B was kept constant at $100 \%$; from 20 to 25 min B was decreased from $100 \%$ to $0 \%$; a post-run time of 5 min was done to equilibrate the column before the next injection. The flow rate was maintained at $1 \mathrm{~mL} \mathrm{~min} \mathrm{~m}^{-1}$ for $25 \mathrm{~min}$ and the injection volume was $50 \mu \mathrm{L}$. The evaporative light scattering detector used nitrogen as the nebulizing gas. The optimal detector conditions were at $1.5 \mathrm{~L} \mathrm{~min}^{-1}$ and $110^{\circ} \mathrm{C}$.

\subsection{Quantitative analysis and statistical treatment}

Six phospholipid classes were identified. The peak area of each phospholipid class was used as an analytical signal. The quantification of each different phospholipid class was carried out using a calibration curve by injecting standard solutions of the different species identified. A representative chromatogram report of phospholipid classes from intramuscular fat and the corresponding peak identifications are shown in Figure 1.

The phospholipid classes identified were considered as chemical descriptors. A data matrix, whose rows are the samples and whose columns are the variables, was built. Each element of this matrix $x_{i j}$ corresponds to the content of phospholipid $\mathrm{j}$ for the sample i. Statistical analysis based on non-parametric techniques were used, including the Kolmogorov-Smirnov-Lilliefors test, which was used to evaluate the normality of each variable included in the study. Since the data distribution was not normal, non-parametric tests were applied. The Kruskal-Wallis test was used to find out significant differences for the variables with three levels. This test is a one way analysis of variance by ranks, i.e., the nonparametric equivalence of one way ANOVA. Kruskal-Wallis test calculates the $\mathrm{H}$ parameter for comparison with the chi-squared distribution for $n-1$ degrees of freedom and $p=0.05$, where $\mathrm{n}$ is the number of groups being considered. When significant differences are detected, a post hoc comparison highlights the pairs of groups responsible for those differences. The Mann-Whitney $U$ test was used to determinate the differences between two levels of the same variable. This test is the nonparametric alternative to the t-Student test for independent means. The statistical parameter $U$ was obtained for each compound, and the respective $z$ values were calculated to be compared with the $z$ value

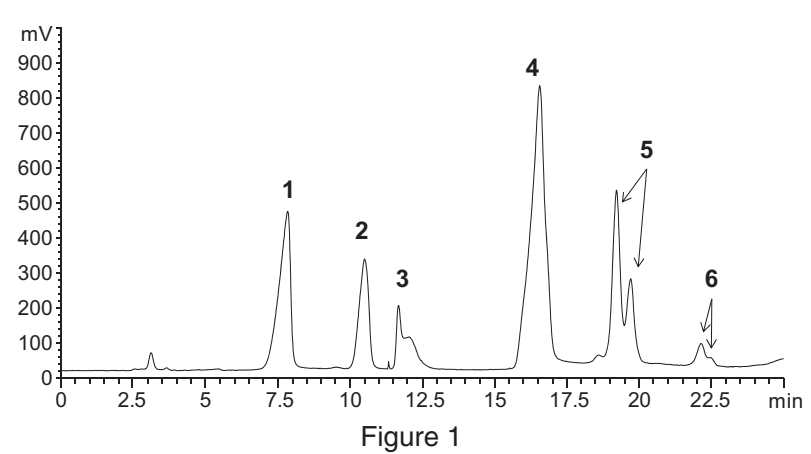

HPLC chromatogram of phospholipid fractions of intramuscular fat from pork loin. 1: Cardiolipin; 2: phosphatidylethanolamine; 3: phosphatidylinositol; 4: phosphatidylcholine;

5: sphingomyelin; 6: lysophosphatidylcholine. 
in the normalized standard distribution. The calculations were made using the statistical package CSS: STATISTICA from StafsoftTM (Tulsa, OK, USA).

\section{RESULTS}

Table 2 shows the mean and standard deviation values $\left(\mathrm{ng} \mathrm{g}^{-1}\right.$ of fat and relative percentage of total phospholipid fraction) for the phospholipid classes determined in the analyzed fat samples grouped according to the two types of loin (fresh and marinated). The profile obtained for the different classes of phospholipids in fresh loin is in good agreement with those reported by other authors except for SPH (7.19\%), which was greater than that described in the literature $(1.8 \%)$ (Meynier et al., 1998) and the LPC $(2.84 \%)$, which is rarely described in this type of samples (Kuchmak and Dugan, 1963) Although it has been found by other authors in pork (Boselli et al., 2008) and in the muscle of other animals, namely rabbit (Cambero et al., 1991), PS was not detected. The averages and ranges of all the samples and groups of fresh and marinated pork loin are included in Table 3. Evidently, the most abundant phospholipid class was PC, with average values of $23.73 \mathrm{ng} \mathrm{g}^{-1}$. The other major phospholipid was PE with an average value of $9.44 \mathrm{ng} \mathrm{g}^{-1}$. CL, PI, SPH and LPC presented concentrations in the range of 1.03-2.45 $\mathrm{ng} \mathrm{g}^{-1}$. In the case of PE, PI, PC, SPH and LPC, samples obtained from fresh loin presented higher average values than those from marinated loin. The CL content was, however, higher in marinated loin. In order to determine significant differences between the two types of loin, the Mann-Whitney $U$ test was performed. The statistical parameter $U$ was obtained for each compound and the respective $z$-values were calculated for comparison with the $z$-value in the normalized standard distribution for $95 \%$ confidence $(z=1.96)$. The results of this test are also shown in table 3 . It can be observed that the obtained $z$-values were higher than the critical one for all of the variables considered. The greatest differences were found for $\mathrm{CL}$ and $\mathrm{SPH}$, with z-values of up to 4 . The other phospholipids presented z-values of up to 2.5 (in absolute value).

According to the results obtained for the different phospholipid classes, the different packaging systems of non-irradiated and irradiated pork loin were treated separately in fresh and marinated loin.

\section{DISCUSSION}

As far as we are aware, studies about changes in each phospholipid class with different irradiation and packaging during storage have not been previously reported.

Table 2

Mean and standard deviation values for the phospholipid classes determined in the loin fat samples

\begin{tabular}{lccccc}
\hline & \multicolumn{2}{c}{ Fresh $(\mathbf{n}=\mathbf{2 7})$} & & \multicolumn{2}{c}{ Marinated $(\mathbf{n}=\mathbf{2 7})$} \\
\cline { 2 - 3 } \cline { 5 - 6 } & Mean $\left(\mathbf{n g ~ g}^{-1}\right)$ & Mean $(\%)$ & & Mean $\left(\mathbf{n g ~ g}^{-1}\right)$ & Mean (\%) \\
\hline $\mathrm{CL}$ & $1.41 \pm 0.99$ & $2.93 \pm 2.17$ & & $3.11 \pm 1.32$ & $8.28 \pm 2.16$ \\
$\mathrm{PE}$ & $12.41 \pm 5.33$ & $23.93 \pm 7.24$ & & $8.14 \pm 5.64$ & $20.27 \pm 5.67$ \\
$\mathrm{PI}$ & $3.03 \pm 1.46$ & $5.91 \pm 2.42$ & & $2.10 \pm 0.91$ & $5.52 \pm 0.65$ \\
$\mathrm{PC}$ & $33.30 \pm 20.60$ & $57.20 \pm 11.38$ & & $21.75 \pm 7.92$ & $57.64 \pm 4.02$ \\
$\mathrm{SPH}$ & $3.68 \pm 1.57$ & $7.19 \pm 2.37$ & & $2.11 \pm 0.93$ & $5.57 \pm 0.77$ \\
$\mathrm{LPC}$ & $1.40 \pm 0.61$ & $2.84 \pm 1.29$ & & $1.00 \pm 0.54$ & $2.72 \pm 1.25$ \\
\hline
\end{tabular}

Table 3

Means and ranges of phospholipid classes $\left(\mathrm{ng} \mathrm{g}^{-1}\right)$ and Mann-Whitney $\mathrm{U}$ Test By variable. Type Marked tests are significant at $p<0.05$

\begin{tabular}{lcccrr}
\hline & $\begin{array}{c}\text { All samples } \\
(\mathbf{n}=\mathbf{5 4})\end{array}$ & Fresh $(\mathbf{n}=\mathbf{2 7})$ & Marinated $(\mathbf{n}=\mathbf{2 7})$ & $\mathbf{U}$ & $\mathbf{Z}$ \\
\hline $\mathrm{CL}^{\mathrm{d}}$ & $1.87(0.00-7.07)$ & $1.42(0.00-4.61)$ & $3.13(1.21-7.07)$ & 82.0000 & -4.88724 \\
$\mathrm{PE}^{\mathrm{c}}$ & $9.44(1.82-31.50)$ & $12.95(1.82-27.24)$ & $5.52(3.30-31.50)$ & 150.0000 & 3.71084 \\
$\mathrm{PI}^{\mathrm{b}}$ & $2.30(0.52-6.72)$ & $2.69(0.52-6.72)$ & $1.88(1.14-4.79)$ & 196.0000 & 2.91505 \\
$\mathrm{PC}^{\mathrm{a}}$ & $23.73(3.80-99.24)$ & $33.63(3.80-99.24)$ & $20.18(10.49-41.59)$ & 217.0000 & 2.55175 \\
$\mathrm{SPH}^{\mathrm{d}}$ & $2.45(0.94-7.50)$ & $3.57(0.94-7.50)$ & $1.90(1.13-5.22)$ & 117.0000 & 4.28174 \\
$\mathrm{LPC}^{\mathrm{b}}$ & $1.03(0.36-2.58)$ & $1.26(0.36-2.58)$ & $0.83(0.42-2.32)$ & 213.0000 & 2.62095 \\
\hline
\end{tabular}

${ }^{a}$ for $p<0.05 ;^{b}$ for $p<0.01 ;^{c}$ for $p<0.001$ and ${ }^{d}$ for $p<0.0001$. 
The end of the shelflife of samples was established when the microbial load reached the value of $107 \mathrm{cfu} \mathrm{\textrm {g } ^ { - 1 }}$ (Cabeza et al., 2007). Accordingly, the shelflife of both fresh and marinated loin stored under the selected conditions will be different according to the strength of the method of microbiota inhibition. However, the statistical analysis showed that these differences did not affect the integrity of most of the phospholipid classes. The normality of the variables in the comparison groups was studied by means of the Kolmogorov - Smirnov Lilliefors test. In light of the results of this test, nonparametric tests, such as the Kruskal-Wallis and Mann-Whitney $U$ test, were used for all betweengroup comparisons.

In order to determine the significant differences between different phospholipid classes for two time values used and both types of samples, a MannWhitney $U$ test was performed. The statistical parameter $U$ was obtained for each compound and the respective $z$-values were calculated for comparison with the $\mathrm{z}$-value in the normalized standard distribution for 95\% confidence. Table 4 shows the results of this application. It can be observed that significant differences $(p<0.01)$ have been found for $\mathrm{PI}$ in fresh loin, showing a lower level for shelflife. PE also presented a reduction, but the difference between these two states was not significant. These decreases can be due to the oxidation of fatty acids from these phospholipid classes. Although the fatty acid compositions of each phospholipid class from the subcutaneous or intramuscular fat of white pork have not been studied, this has been done in Iberian ham, where PE and PI showed the highest contents in C22:6 (n-6) and C22:6 (n-3) acids (Nárvaez-Rivas et al., 2011). This composition could favor the oxidation of the fatty acids and the concomitant loss of these phospholipid classes. This effect may be attributed to the availability of oxygen during the E-beam treatment. Ozone (Olson 1998) and oxygen peroxide (Whitburn et al., 1982) are produced by radiolysis of water. Both compounds are strong oxidizing agents which, in turn, could work together with the oxygen in the atmosphere (not in the vacuum packaged) for oxidizing the phospholipid fatty acids, as it is well known that they are endowed with a high degree of instauration. However, no differences have been found for marinated loin, which could be explained by the presence of ascorbic acid in these samples since this may act as a reducing agent.

In Table 5, the results obtained from the MannWhitney $U$ test to study the effect of temperature are presented for both kinds of samples (fresh and marinated). Two temperatures (4 and $8^{\circ} \mathrm{C}$ ) have been applied for storage. Only significant differences $(p<0.05)$ are observed for $C L$ in the fresh loin. There are no references about the effect of temperature in phospholipid classes. So it

Table 4

Mann-Whitney $U$ Test according to time for both types of sample. Marked tests are significant at $p<0.05$

\begin{tabular}{lcccccccc}
\hline & \multicolumn{3}{c}{ Fresh $(\mathbf{n}=\mathbf{2 7})$} & & \multicolumn{3}{c}{ Marinated $(\mathbf{n}=\mathbf{2 7})$} \\
\cline { 2 - 4 } \cline { 7 - 8 } & $\mathbf{U}$ & $\mathbf{Z}$ & p-level & & $\mathbf{U}$ & $\mathbf{Z}$ & p-level \\
\hline $\mathrm{CL}$ & 49.00000 & -1.64590 & 0.099785 & & 76.00000 & 0.25717 & 0.797046 \\
$\mathrm{PE}$ & 50.00000 & 1.59447 & 0.110832 & & 80.00000 & -0.05143 & 0.958979 \\
$\mathrm{PI}$ & 29.00000 & 2.67459 & 0.007482 & & 62.00000 & 0.97725 & 0.328444 \\
$\mathrm{PC}$ & 76.00000 & 0.25717 & 0.797046 & & 78.00000 & 0.15430 & 0.877371 \\
SPH & 67.00000 & 0.72008 & 0.471475 & & 78.00000 & -0.15430 & 0.877371 \\
LPC & 78.00000 & -0.15430 & 0.877371 & & 60.00000 & -1.08012 & 0.280088 \\
\hline
\end{tabular}

Table 5

Mann-Whitney U Test according to temperature for both types of sample. Marked tests are significant at $p<0.05$

\begin{tabular}{lccccccc}
\hline & \multicolumn{3}{c}{ Fresh $(\mathbf{n}=\mathbf{2 7})$} & & \multicolumn{3}{c}{ Marinated $\mathbf{( n = 2 7 )}$} \\
\cline { 2 - 4 } \cline { 7 - 8 } & $\mathbf{U}$ & $\mathbf{Z}$ & p-level & & $\mathbf{U}$ & $\mathbf{Z}$ & p-level \\
\hline $\mathrm{CL}$ & 33.00000 & -2.46885 & 0.013555 & & 56.00000 & 1.285861 & 0.198492 \\
$\mathrm{PE}$ & 53.00000 & 1.44016 & 0.149822 & & 74.00000 & 0.360041 & 0.718817 \\
$\mathrm{PI}$ & 53.00000 & 1.44016 & 0.149822 & & 44.00000 & 1.903075 & 0.057032 \\
$\mathrm{PC}$ & 80.00000 & 0.05143 & 0.958979 & & 54.00000 & 1.388730 & 0.164916 \\
$\mathrm{SPH}$ & 76.00000 & -0.25717 & 0.797046 & & 51.00000 & 1.543033 & 0.122824 \\
LPC & 44.00000 & -1.90307 & 0.057032 & & 64.00000 & 0.874386 & 0.381909 \\
\hline
\end{tabular}


seems that CP fatty acids are more prone to being oxidized, yielding a higher phospholipid molecule fragmentation. In the marinated loin, again no differences have been found, possibly because of the additives used.

In addition, the effect of packaging atmosphere (air, MAP and vacuum) has been studied by applying a Kruskal-Wallis test. The results are shown in Table 6 and it can be deduced that there are significant differences $(p<0.05)$ between MAP and vacuum for $P E$ in the case of marinated loin, with the highest mean value in MAP. This fact has no explanation and no references about it have been found. On the contrary, the packaging atmosphere has no effect on phospholipid classes from fresh loin.

Finally, several irradiation doses have been used for both types of loin (0,1 and 2 kGy). The effect of this was also studied using a Kruskal-Wallis test, whose data are presented in Table 7. No effect of the irradiation doses (until 2 kGy) on changes in the individual phospholipids was observed, which is a valuable result since E-beam may be applied as a useful tool to extend the shelf-life of fresh loin without alterations in, perhaps, the most sensitive molecules of the meat lipid fraction.

\section{CONCLUSIONS}

In this work, a study of the effects of E-beam irradiation and packaging on the phospholipid classes from fresh and marinated pork loin has been carried out for the first time. The HPLC/ELSD method is a rapid, sensitive and highly reproducible procedure for the separation and quantification of the different phospholipid classes in a given sample.

\section{ACKNOWLEDGMENTS}

The authors are grateful to Prof. J.A. Ordóñez for her help and advice. This study was supported by projects P08-AGR-03498, AGL2007-65235-C02-02 and CSD 2007-00016 of the program CONSOLIDER INGENIO 2010.

\section{REFERENCES}

Ahn DU, Jo C, Du M, Olson DG, Nam KC. 2000. Quality characteristics of pork patties irradiated and stored in different packaging and storage conditions. Meat Sci. 56, 203-209.

Table 6

Significant differences within both types of sample (fresh and marinated) for the phospholipid classes analyzed according to the different packaging atmospheres (air, MAP and vacuum)

\begin{tabular}{|c|c|c|c|c|c|c|c|c|}
\hline & \multicolumn{4}{|c|}{ Fresh $(n=27)$} & \multicolumn{4}{|c|}{ Marinated $(n=27)$} \\
\hline & H & $A / V$ & A/MAP & V/MAP & $\mathbf{H}$ & A/V & A/MAP & V/MAP \\
\hline$C L$ & 0.61 & ns & ns & ns & 1.06 & ns & ns & ns \\
\hline PE & 5.77 & ns & ns & ns & 6.11 & ns & ns & * \\
\hline PI & 6.18 & ns & ns & ns & 4.09 & ns & ns & ns \\
\hline PC & 1.63 & ns & ns & ns & 5.14 & ns & ns & ns \\
\hline $\mathrm{SPH}$ & 4.28 & ns & ns & ns & 4.02 & ns & ns & ns \\
\hline LPC & 6.10 & ns & ns & ns & 0.32 & ns & ns & ns \\
\hline
\end{tabular}

$\mathrm{ns}$, not significant; $* \mathrm{p}<0.05$; air: A; vacuum: $\mathrm{V}$. Comparison between packaging atmospheres using Kruskal-Wallis Test.

Table 7

Significant differences within both types of samples (fresh and marinated) for the phospholipid classes analyzed according to the different irradiation doses (0, 1 and 2 kGy)

\begin{tabular}{|c|c|c|c|c|c|c|c|c|}
\hline & \multicolumn{4}{|c|}{ Fresh $(n=27)$} & \multicolumn{4}{|c|}{ Marinated $(n=27)$} \\
\hline & $\mathbf{H}$ & $0 / 1$ & $0 / 2$ & $1 / 2$ & $\mathbf{H}$ & $0 / 1$ & $0 / 2$ & $1 / 2$ \\
\hline$C L$ & 0.06 & ns & ns & ns & 2.61 & ns & ns & ns \\
\hline PE & 1.60 & ns & ns & ns & 2.92 & ns & ns & ns \\
\hline $\mathrm{PI}$ & 1.47 & ns & ns & ns & 3.52 & ns & ns & ns \\
\hline PC & 1.07 & ns & ns & ns & 2.29 & ns & ns & ns \\
\hline $\mathrm{SPH}$ & 0.84 & ns & ns & ns & 3.35 & ns & ns & ns \\
\hline LPC & 0.87 & ns & ns & ns & 0.47 & ns & ns & ns \\
\hline
\end{tabular}

ns, not significant; Comparison between irradiation doses using Kruskal-Wallis Test. 
Ali MS, Kang GH, Yang HS. 2007. A Comparison of meat characteristics between duck and chicken breast. Asian Australas J. Anim. Sci. 20, 1002-1006.

Boselli E, Pacetti D, Curzi F, Frega NG. 2008. Determination of phospholipid molecular species in pork meat by high performance liquid chromatographytandem mass spectrometry and evaporative light scattering detection. Meat Sci. 78, 305-313.

Cabeza MC, Cambero MI, Hoz L, Ordóñez JA. 2007. Optimization of E-beam treatment to eliminate Listeria monocytogenes from ready-to-eat (RTE) cooked ham. Innov. Food Sci. Emerg. Tech. 8, 299-305.

Cabeza MC, de la Hoz L, Velasco R, Cambero MI, Ordóñez JA. 2009. Safety and quality of ready-toeat dry fermented sausages subjected to E-beam radiation. Meat Sci. 83, 320-327.

Cambero MI, de la Hoz L, Sanz B, Ordóñez JA. 1991. Lipid and Fatty Acid Composition of Rabbit Meat: Part 2. DPhospholipids. Meat Sci. 29, 167-176.

Candek-Potokar M, Zlender B, Lefoucher L, Bonneau M. 1998. Effects of age and/or slaughter weight at slaughter on LM: Biochemical and sensory quality in pigs. Meat Sci. 48, 287-300.

Chen X, Jo C, Lee JI, Ahn DU. 1999. Lipid Oxidation, Volatiles and Color Changes of Irradiated Pork Patties as Affected by Antioxidants. J. Food Sci. 64, 16-19.

Chiu EM, Kuo MC, Bruechert LJ, Ho CT. 1990. Substitution of pyrazines by aldehydes inmodel systems. J. Agric. Food Chem. 38, 58-61.

Choi YH. 2009. Conjugated linoleic acid as a key regulator of performance, lipid metabolism, development, stress and immune functions, and gene expression in chickens. Asian Australas J. Anim. Sci. 22, 448-458.

Church IJ, Parsons AL. 1995. Modified atmosphere packaging technology: a review. J. Sci. Food Agric. 67, 143-152.

Dainty RH, Mackey BM. 1992. The relationship between the phenotypic properties of bacteria from chill-stored meat and spoilage processes. J. Appl. Bacteriol. (Symposium Suppl) 73, 103-114.

Du M, Ahn DU, Mendonca AF, Wesley IV. 2002. Quality characteristics of irradiated ready-to-eat breast rolls from turkeys fed conjugated linoleic acid. Poultry Sci. 81, 1378-1384.

Folch J, Lees M, Stanley GHS. 1957. A simple method for the isolation and purification of total lipids from animal tissues. J. Biol. Chem. 226, 497-509.

Gandemer G. 2002. Lipids in muscles and adipose tissues: Changes during processing and sensory properties of meat products. Meat Sci. 62, 309-321.

García RJA, Gibert J, Díaz, I. 1994. Determination of neutral lipids from subcutaneous fat of cured ham by capillary gas chromatography and liquid chromatography. J. Chrom. 667, 225-233.

Groninger HS, Tappel AL, Knapp, FW. 1956. Some chemical and organoleptic changes in gamma irradiated meats. Food Res. 21, 555-564.

Hoz L, Cambero MI, Cabeza MC, Herrero AM, Ordóñez, JA. 2008. Elimination of Listeria monocyogenes from vacuum-packed dry-cured ham by e-beam radiation. J. Food Protect 71, 2001-2006.

Huang YC, Li HJ, He ZF, Wang T, Qin G. 2010. Study on the Flavor Contribution of Phospholipids and Triglycerides to Pork. Food Sci. Biotechnol. 19, 1267 1276.

Huff-Lonergan E, Baas TJ, Malek M, Dekkers JC, Prusa K, Rothschild MF. 2002. Correlations among selected pork quality traits. J. Anim. Sci. 80, 617-627.
Kuchmak M, Dugan LR. 1963. Phospholipids of pork muscle tissues. J. Am. Oil Chem. Soc. 40, 734-736.

Lambert AD, Smith JP, Dodds K. 1992. Physical, chemical and sensory changes in irradiated fresh pork packaged in modified atmosphere. J. Food Sci. 57, 1294-1299.

Lefebvre N, Thibault C, Charbonneau R, Piette, JP. 1994. Improvement of shelf-life and wholesomeness of ground beef by irradiation. 2. Chemical analysis and sensory evaluation. Meat Sci. 36, 371-380.

Livingston M, Brewer MS, Killifer J, Bidner B, McKeith F. 2004. Shelf life characteristics of enhanced modified atmosphere packaged pork. Meat Sci. 68, 115-122.

Lonergan SM, Huff-Lonergan E, Rowe LJ, Kuhlers DL, Jungst SB. 2001. Selection for lean growth efficiency in Duroc pigs: Influence on pork quality. J. Anim. Sci. 79, 2075-2085.

Meynier A, Genot C, Gandemer G. 1998. Volatile Compounds of Oxidized Pork Phospholipids. J. Am. Oil Chem. Soc. 75, 1-7.

Ministerio de Comercio Exterior, (Documento preliminar), Actualizado el 5/10/072007, Acuerdo de asociación entre centro América y la UE.

MARM (Ministerio de Medio Ambiente, Medio Rural y Marino), 2000. Estudio sobre la comercialización agroalimentaria en el sector cooperativo español. CAPITULO V: Promoción y exportación de la carne de porcino en el entorno cooperativo.

Mitchell GE. 1994. Irradiation preservation of meats. Food Aust. 46, 512-517.

Mottram DS, Whitfield FB. 1995. Volatiles compounds from the reaction of cysteine, ribose, and phospholipids in low moisture systems. J. Agric. Food Chem. 43, 984-988.

Narváez-Rivas M, Gallardo M, Rios JJ, LeónCamacho M. 2011. A new high-performance liquid chromatographic method with evaporative light scattering detector for the analysis of phospholipids. Application to Iberian pig subcutaneous fat. J. Chrom. A 1218, 3453-3458.

Olson DG. 1998. Irradiation of food: Scientific status summary. Food Techol. 52, 56-62.

Olsson C, Ahrne' S, Pettersson B, Molina G. 2003. The bacterial flora of fresh and chill-stored pork: analysis by cloning and sequencing of 16S RNA genes. Int. J. Food Microbiol. 83, 245-252.

Patterson RL, Stevenson MH. 1995. Irradiation-induced off-odor in chicken and its possible control. Brit. Poultry Sci. 36, 425-441.

Sasaki K, Ishihara K, Oyamada C. 2008. Effects of fucoxanthin addition to ground chicken breast meat on lipid and colour stability during chilled storage, before and after cooking. Asian Australas J. Anim. Sci. 21, 1067-1072.

Thayer DW, Fox JB, Lakritz L. 1993. Chapter 23: Effects of ionizing radiation treatments on the microbiological, nutritional, and structural quality of meats, in Spanier AM, Okai $\mathrm{H}$ and Tamura M (Ed.) Food Flavor and Safety. Am. Chem. Soc. 294-302.

Weihrauch JL, Son YS. 1983. The phospholipids content of foods. J. Am. Oil Chem. Soc. 60, 1971-1978.

Whitburn KD, Shieh JJ, Sellers RM, Hoffmann MZ, Taub, IA. 1982. Redox transformations in ferrimyglobin induced by radiation-generated free radicals in aqueous solution. J. Biol. Chem. 257, 1860-1869. 